\title{
Exploring the Paradoxical Relationship of a Creb 3 Regulatory Factor Missense Variant With Body Mass Index and Diabetes Among Samoans: Protocol for the Soifua Manuia (Good Health) Observational Cohort Study
}

Nicola L Hawley ${ }^{1}$, BSc, PhD; Alysa Pomer ${ }^{1}$, BA, MA, MS, PhD; Anna C. Rivara ${ }^{1}$, BS, MA, MPH, PhD; Samantha L Rosenthal $^{2}$, BA, PhD; Rachel L Duckham ${ }^{3,4}$, BS, MS, PhD; Jenna C Carlson ${ }^{5}$, BS, PhD; Take Naseri ${ }^{6}$, BSc, MD, MPH; Muagututia Sefuiva Reupena ${ }^{7}$, BA, MA; Melania Selu ${ }^{8}$; Vaimoana Lupematisila ${ }^{8}$; Folla Unasa ${ }^{8}$; Lupesina Vesi $^{8}$; Tracy Fatu ${ }^{8}$; Seipepa Unasa ${ }^{8}$; Kima Faasalele-Savusa ${ }^{8}$, BM; Abigail I Wetzel ${ }^{9}$, BS; Christina Soti-Ulberg ${ }^{6}$, BSc; Angela T Prescott ${ }^{10}$, BA, MD; Gloria Siufaga ${ }^{8}$; Corina Penaia ${ }^{11}$, BA; Sophie B. To ${ }^{12}$, BA, MPH; Lauren C LaMonica $^{1}$, BA, MPH; Viali Lameko ${ }^{13}$, BSc, MD, MPH; Courtney C Choy ${ }^{9}$, BA, MPH; Scott E Crouter ${ }^{14}$, BS, MS, PhD; Susan Redline ${ }^{15}$, BA, MD, MPH; Ranjan Deka ${ }^{16}$, PhD; Erin E Kershaw ${ }^{17^{*}}$, BA, MD; Zsolt Urban ${ }^{2 *}$, MS, PhD; Ryan L. Minster ${ }^{2^{*}}$, BS, MSIS, PhD; Daniel E. Weeks ${ }^{2^{*}}$, BA, MS, PhD; Stephen T McGarvey ${ }^{9}, 8^{*}$, BA, MA, PhD, MPH

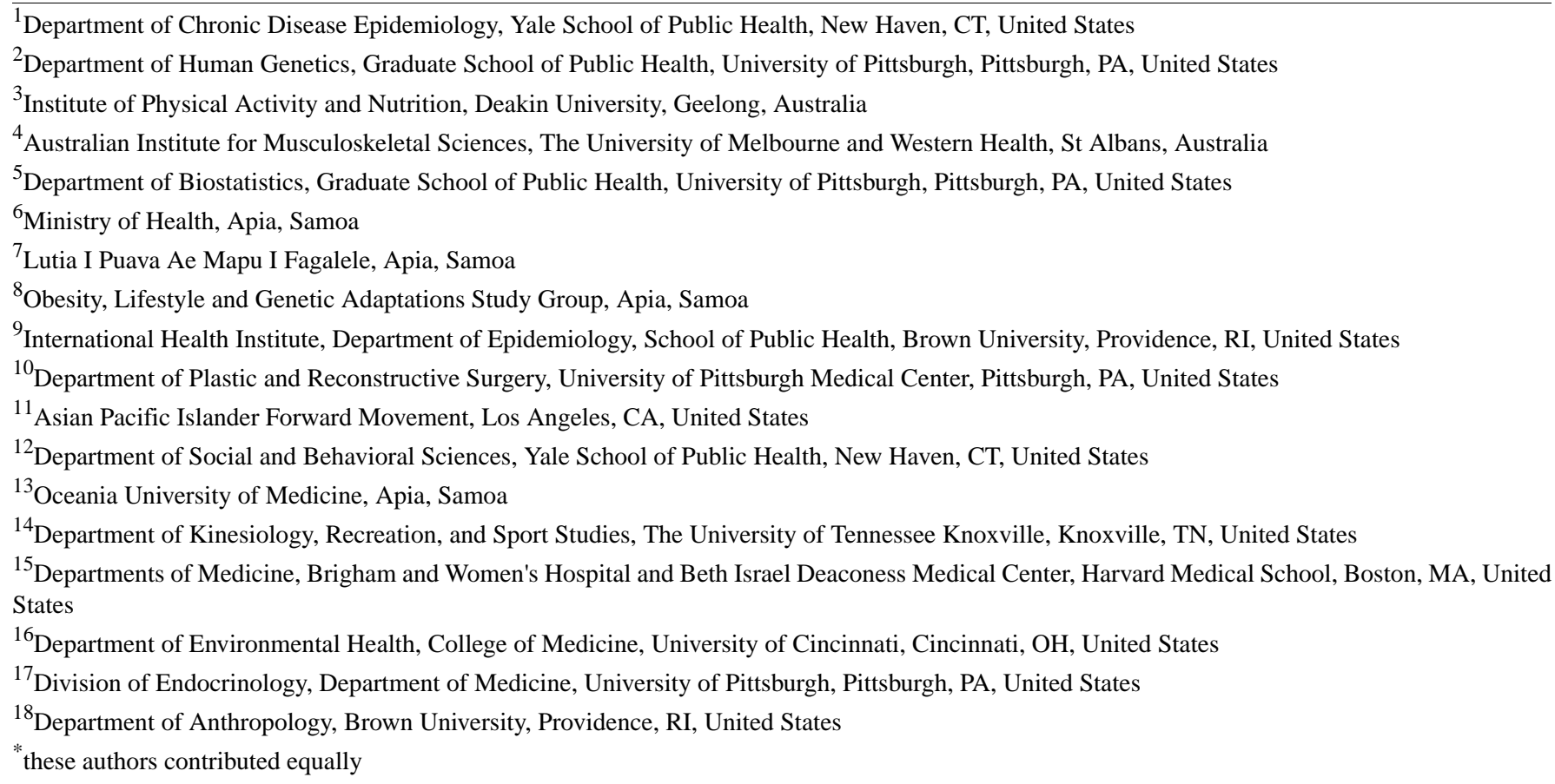

\section{Corresponding Author:}

Nicola L Hawley, BSc, PhD

Department of Chronic Disease Epidemiology

Yale School of Public Health

60 College Street

New Haven, CT, 06520

United States

Phone: 12037377176

Email: nicola.hawley@yale.edu

\section{Abstract}


Background: The prevalence of obesity and diabetes in Samoa, like many other Pacific Island nations, has reached epidemic proportions. Although the etiology of these conditions can be largely attributed to the rapidly changing economic and nutritional environment, a recently identified genetic variant, rs373863828 (CREB 3 regulatory factor, CREBRF: c.1370G>A p.[R457Q]) is associated with increased odds of obesity, but paradoxically, decreased odds of diabetes.

Objective: The overarching goal of the Soifua Manuia (Good Health) study was to precisely characterize the association of the CREBRF variant with metabolic (body composition and glucose homeostasis) and behavioral traits (dietary intake, physical activity, sleep, and weight control behaviors) that influence energy homeostasis in 500 adults.

Methods: A cohort of adult Samoans who participated in a genome-wide association study of adiposity in Samoa in 2010 was followed up, based on the presence or absence of the CREBRF variant, between August 2017 and March 2019. Over a period of 7-10 days, each participant completed the main study protocol, which consisted of anthropometric measurements (weight, height, circumferences, and skinfolds), body composition assessment (bioelectrical impedance and dual-energy x-ray absorptiometry), point-of-care glycated hemoglobin measurement, a fasting blood draw and oral glucose tolerance test, urine collection, blood pressure measurement, hand grip strength measurement, objective physical activity and sleep apnea monitoring, and questionnaire measures (eg, health interview, cigarette and alcohol use, food frequency questionnaire, socioeconomic position, stress, social support, food and water insecurity, sleep, body image, and dietary preferences). In January 2019, a subsample of the study participants $(n=118)$ completed a buttock fat biopsy procedure to collect subcutaneous adipose tissue samples.

Results: Enrollment of 519 participants was completed in March 2019. Data analyses are ongoing, with results expected in 2020 and 2021.

Conclusions: While the genetic variant rs373863828, in CREBRF, has the largest known effect size of any identified common obesity gene, very little is currently understood about the mechanisms by which it confers increased odds of obesity but paradoxically lowered odds of type 2 diabetes. The results of this study will provide insights into how the gene functions on a whole-body level, which could provide novel targets to prevent or treat obesity, diabetes, and associated metabolic disorders. This study represents the human arm of a comprehensive and integrated approach involving humans as well as preclinical models that will provide novel insights into metabolic disease.

International Registered Report Identifier (IRRID): RR1-10.2196/17329

(JMIR Res Protoc 2020;9(7):e17329) doi: 10.2196/17329

\section{KEYWORDS}

cohort studies; CREBRF; type 2 diabetes; obesity; Samoa

\section{Introduction}

\section{Background}

As is now the case in many Pacific Island nations, the prevalence of obesity and diabetes in Samoa have reached epidemic proportions. In 2013 (the most recent estimates), $41.2 \%$ of men and $65.1 \%$ of women could be classified as having obesity based on Polynesian-specific body mass index (BMI) cutoff points $\left(>32 \mathrm{~kg} / \mathrm{m}^{2}\right)$ [1]. Data from the same survey indicated that type 2 diabetes mellitus was present in $19.6 \%$ of men and $19.5 \%$ of women and projections suggest that the proportion of the population with diabetes may exceed $26 \%$ by 2020 [1].

The underlying etiology of the rapidly increasing prevalence of obesity and related cardiometabolic disorders in the Pacific generally [2,3], and Samoa specifically [1], can be attributed in large part to the rapidly changing economic and nutritional environment. While energy availability, often in the form of calorie-dense, nutrient-poor, imported foods has increased rapidly in recent decades [4], opportunities for subsistence agriculture-related physical activity have simultaneously declined, resulting in chronic positive energy balance and associated metabolic disease. Perhaps compounding the effect of the changing nutritional and physical activity environment, however, is a recently identified genetic variant, rs373863828 (CREB 3 regulatory factor, $C R E B R F: \mathrm{c} .1370 \mathrm{G}>\mathrm{A}$ p.[R457Q]), which is associated with increased odds of obesity, but paradoxically, decreased odds of diabetes [5].

The $C R E B R F$ missense variant $(C R E B R F)$, first identified in a genome-wide association study (GWAS) we conducted in 2010 [5], is common among Samoans (minor allele frequency=0.259) and has a larger effect on BMI than any previously identified common genetic variant. The minor allele (A) is associated with greater average adult BMI of $1.36 \mathrm{~kg} / \mathrm{m}^{2}$ per copy, an effect size approximately 3 -fold greater than variation near FTO $(0.39$ $\mathrm{kg} / \mathrm{m}^{2}$ per copy) [6]. Interestingly, however, the higher-BMI allele is associated with decreased odds of type 2 diabetes and lower fasting serum glucose levels. Several studies in New Zealand Māori and Pacific Islanders (Tongans, Cook Islanders, and Niueans) have recently replicated these findings [7-11], demonstrating comparable minor allele frequencies and reproducing the incongruent effects on BMI and type 2 diabetes. The variant is nearly absent in non-Pacific Islanders (14 alleles in 198,121 individuals, allele frequency $=0.00004$ in BRAVO and the Genome Aggregation Database (gnomAD) combined) $[12,13]$.

Findings from mouse cell models indicate that the CREBRF genetic variant plays a role in both adipogenesis and improving cell survival under starvation conditions [5]. It appears to function by reducing energy substrate utilization for basic cellular processes and reallocating energy to lipid storage, perhaps functioning as a "thrifty gene" [5]. How the gene 
functions on a whole-body level and the underlying explanation for its paradoxical association with obesity and diabetes, however, remains unknown.

\section{Objectives}

The overarching goal of this study was to precisely characterize the impact of the CREBRF variant on metabolic (body composition and glucose homeostasis) and behavioral traits (dietary intake, physical activity, sleep, and weight control behaviors) that influence energy homeostasis in 500 adults. Specifically, we aimed to (1) determine if the CREBRF variant's paradoxical association with BMI and diabetes could be explained by the amount (total fat mass) and distribution of adiposity (subcutaneous relative to visceral or central versus peripheral); (2) determine the association of the CREBRF variant with measures of glucose homeostasis and insulin action; (3) explore gene-environment interactions among the CREBRF variant and dietary intake, physical activity, and other behavioral traits; and (4) understand how the CREBRF variant influences metabolic homeostasis and gene expression in human adipose tissue.

\section{Methods}

\section{Study Design}

The Soifua Manuia (Good Health in Samoan) study described here follows a cohort of adult Samoans who participated in a GWAS of adiposity in Samoa in 2010 and who were followed up, based on the presence or absence of the CREBRF genetic variant, between August 2017 and March 2019. The recruitment procedures and protocols associated with the 2010 GWAS study have been described in detail previously [14]. This study protocol describes the procedures used during the 2017-2019 interaction with study participants.

The study underwent initial and annual continuing ethical review by institutional review boards (IRBs) at Yale and Brown Universities (there was a reliance agreement between Brown and Yale, with Yale serving as the IRB of record, IRB \#1604017547). Data analysis activities at the University of Pittsburgh were reviewed by their IRB and were determined to be exempt (IRB \#PRO16040077) based on their receipt of only deidentified data. The PartnersHealth Office of Research approved protocols for sleep apnea studies, and all aspects of the protocol were reviewed and approved by the Health Research Committee of the Samoan Ministry of Health. All participants provided written informed consent for their participation.

\section{Setting}

Samoa is an independent Pacific Island nation consisting of 2 large (Upolu and Savai'i) and several smaller islands. The majority of the Samoan population is rural $(81 \%)$, and $78 \%$ are residents on the island of Upolu [15], which is divided into 3 census regions: the Apia urban area (AUA), Northwest Upolu (NWU), and the rest of Upolu (ROU).

Classified as an upper middle-income economy by the World Bank, Samoa's gross national income was US \$4120 per capita in 2017 [16], and the country ranked 104 out of 188 globally based on the Human Development Index (HDI value=0.704)
[17]. In 2017, the population of Samoa was 195,352, with an anticipated annual growth rate of $0.9 \%$. Life expectancy at birth in 2016 was 78 for women and 72 for men [18].

\section{Participants}

Participants included in the 2017-2019 Soifua Manuia study were purposively recruited to study genetic and environmental influences on adiposity and cardiometabolic health. Specifically, we aimed to recruit a sample of 500 participants, with equal numbers of men and women, 100 of whom had 2 copies of the CREBRF minor/risk allele (AA), 200 of whom had one copy (AG), and 200 of whom had zero copies (GG). We carried out this nonrepresentative sampling by genotype to have higher power to detect contrasts between the genotype groups, while recognizing what was feasible in terms of recruitment given the overall rarity of the AA genotype in the population.

CREBRF genotypes were determined based on participants' data from the 2010 GWAS study [5,14]. The original eligibility criteria for the GWAS study included Samoan ethnicity (which was determined based on participant report that they had 4 Samoan grandparents), were aged 24.5 years to less than 65 years, nonpregnant, and had no physical or cognitive impairment that would prohibit completion of study procedures. To create a list of potential participants to be recruited for the 2017-2019 follow-up a number of selection criteria were applied to the 2010 data (Figure 1): only participants who consented in 2010 to being recontacted for additional research studies were included; participants must have had genotype data from the 2010 study and complete data on key outcomes of interest (BMI and serum glucose levels) and must have been resident on the island of Upolu (because study equipment could not be transported to the less developed and less densely populated island of Savai'i, where 9 of 33 of the 2010 GWAS villages were located). Then, kinship estimates were used (GenABEL [19]) to restrict the sample to those who were only minimally related to one another (less than first cousins, maximum kinship estimate $6.01 \%$ ) because reducing the genetic correlation among the sampled individuals increases the effective population size. From this sample, individuals with the AA genotype were prioritized for recruitment. Early on in recruitment, we attempted to recruit 2 AG genotype and 2 GG genotype individuals for each recruited AA genotype individual, matching on sex, age within 5 years, and census region. Halfway through the recruitment, this protocol was adjusted to allow for faster recruitment, prioritizing $\mathrm{AA}$ and $\mathrm{AG}$ genotype individuals without explicitly matching. In this system, target recruitment lists were generated from the list of unrelated individuals and participants were recruited until the desired sample size for each genotype group within sex was achieved.

Recruitment occurred between August 2017 and March 2019 from 23 villages on the island of Upolu ( 8 urban [AUA], 7 periurban [NWU], and 8 rural [ROU]). After government and village-level permissions were granted, Samoan research assistants ( 2 out of 4 of whom had assisted with the 2010 GWAS study) used phone calls and visits to the participants' 2010 villages of residence to relocate participants. Village leadership (village mayors and women's committee members) assisted research staff in locating participants' homes. If a participant 
could not be located, the reason was noted (Figure 1). In the case of participant death, a death certificate was requested from the Samoa Bureau of Statistics to document the cause.

During visits to participants' homes, research staff provided detailed information about the purpose of the 2017-2019 follow-up study and its protocols, gained written informed consent from all participants (including permission to link their 2017-2019 phenotype data with their 2010 data, which had been shared with the database of Genotypes and Phenotypes (dbGap) [20]), and screened the participants for eligibility. The same eligibility criteria were applied in 2017-2019 as in 2010 [14]; pregnant women were excluded, as were those who had developed physical or cognitive impairments preventing full participation in study procedures. Additional exclusion criteria included having given birth in the past 6 months or current lactation, ongoing use of weight loss medications, weight loss surgery, or significant recent weight loss ( $>5 \%$ of body weight in the past year). Seven to nine years after their original participation in the 2010 GWAS study, participants' age ranged from 30.7 years to 72.7 years. A total of 519 participants agreed to participate in the study (Figure 1): 94 participants with the AA CREBRF genotype, 201 with the AG genotype, and 224 with the GG genotype.

\section{Study Procedures}

Willing and eligible participants completed study activities over the course of 7-10 days. Two in-person visits took place, one in the participant's home and the other 7-10 days later in the Obesity, Lifestyle, and Genetic Adaptations (OLaGA; $n$. life in Samoan) research laboratory, located in the capital city of Apia, and research assistants contacted participants once by phone between the in-person visits. During the home visit, research assistants collected height, weight, hemoglobin (for assessment of anemia), administered a number of questionnaires, and initiated an accelerometer-based device, which participants wore to objectively measure physical activity for at least seven days before their visit to the OLaGA laboratory. Remaining study procedures were completed during the laboratory visit. A subsample of participants provided a subcutaneous buttock fat biopsy, which was collected at a separate research visit in January 2019. Participants were compensated for time spent completing the protocol, receiving 75 Western Samoan Tala (WST; approximately US \$28) for their participation as well as a $10 \mathrm{WST}$ phone card to allow them to complete dietary recalls by telephone. Table 1 provides an overview of the study activities and their timing, and each of the procedures are described in detail below. 
Figure 1. Consolidated Standards of Reporting Trials diagram describing recruitment into the Soifua Manuia study and completion of study procedures. GWAS: genome-wide association study; $\mathrm{HbA}^{\mathrm{lc}}$ : glycated hemoglobin.

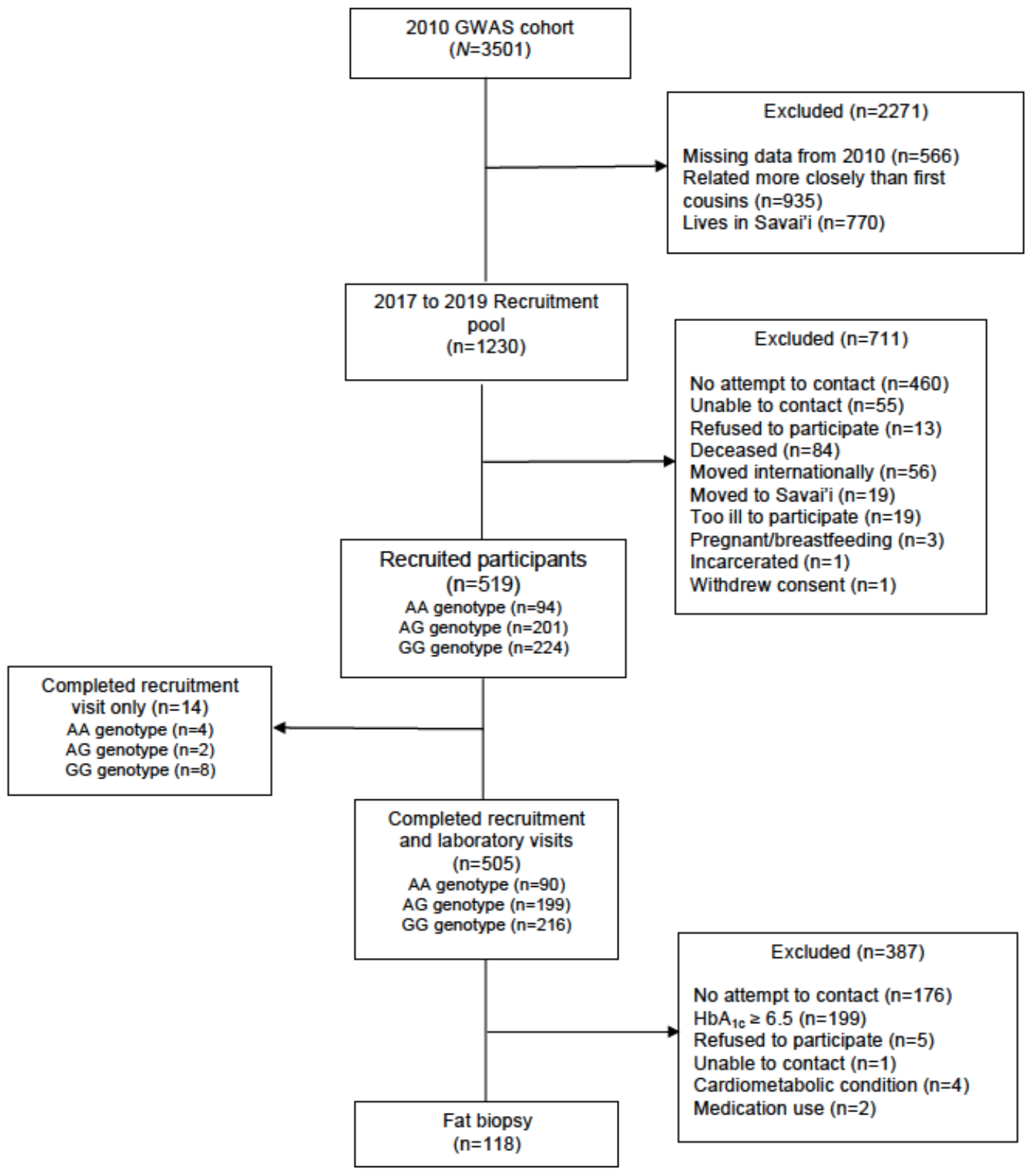


Table 1. Summary of the Soifua Manuia study procedures.

\begin{tabular}{|c|c|c|c|c|}
\hline Measures & 2010 & $\begin{array}{l}\text { Home visit, 2017- } \\
2019\end{array}$ & $\begin{array}{l}\text { Laboratory visit, } 2017- \\
2019\end{array}$ & $\begin{array}{l}\text { Fat biopsy visit, } \\
2019\end{array}$ \\
\hline \multicolumn{5}{|l|}{ Anthropometric measures } \\
\hline Weight & $\mathrm{X}^{\mathrm{a}}$ & $\mathrm{X}$ & $\mathrm{X}$ & $\mathrm{X}$ \\
\hline Height & $\mathrm{X}$ & $\mathrm{X}$ & $\mathrm{X}$ & $\mathrm{X}$ \\
\hline Circumferences (midupper arm, abdominal, hip, and midcalf) & $\mathrm{X}$ & $-\mathrm{b}$ & $\mathrm{X}$ & - \\
\hline $\begin{array}{l}\text { Skinfold thicknesses (forearm, tricep, subscapular, abdominal, } \\
\text { and suprailiac) }\end{array}$ & $\mathrm{X}$ & - & $\mathrm{X}$ & - \\
\hline \multicolumn{5}{|l|}{ Body composition } \\
\hline $\mathrm{BIA}^{\mathrm{c}}$ & $\mathrm{X}$ & - & $\mathrm{X}$ & - \\
\hline DXA $^{\mathrm{d}}$ (total body, lumbar spine, hip, and forearm) & - & - & $\mathrm{X}$ & - \\
\hline \multicolumn{5}{|l|}{ Blood pressure and hand grip strength } \\
\hline Blood pressure and heart rate & $\mathrm{X}$ & - & $\mathrm{X}$ & - \\
\hline Hand grip strength & - & - & $\mathrm{X}$ & - \\
\hline \multicolumn{5}{|l|}{ Biospecimen collection } \\
\hline Hemoglobin & - & $\mathrm{X}$ & - & - \\
\hline Point-of-care $\mathrm{HbA}_{1 \mathrm{c}}{ }^{\mathrm{e}}$ & - & - & $\mathrm{X}$ & $\mathrm{X}$ \\
\hline Point-of-care fasting blood glucose & $\mathrm{X}$ & - & $\mathrm{X}$ & - \\
\hline Serum & $\mathrm{X}$ & - & $\mathrm{X}$ & - \\
\hline OGTT $^{f}$ & - & - & $\mathrm{X}$ & - \\
\hline DNA & $\mathrm{X}$ & - & $\mathrm{X}$ & - \\
\hline RNA & - & - & $\mathrm{X}$ & - \\
\hline Urine & - & - & $\mathrm{X}$ & - \\
\hline Objective physical activity monitoring (ActiGraph GT3X+) & - & $\mathrm{X}$ & $\mathrm{X}$ & - \\
\hline Sleep monitoring (WatchPAT) & - & - & $\mathrm{X}$ & - \\
\hline 24-Hour dietary recalls & - & $\mathrm{X}$ & $\mathrm{X}$ & - \\
\hline \multicolumn{5}{|l|}{ Questionnaire measures $^{\mathrm{g}}$} \\
\hline Demographic information & $\mathrm{X}$ & $\mathrm{X}$ & - & - \\
\hline Health Interview ${ }^{\mathrm{h}}$ & $\mathrm{X}$ & $\mathrm{X}$ & - & $\mathrm{X}$ \\
\hline Women's health & $\mathrm{X}$ & $\mathrm{X}$ & - & - \\
\hline Cigarette and alcohol use & $\mathrm{X}$ & $\mathrm{X}$ & - & - \\
\hline Physical activity & $\mathrm{X}$ & $\mathrm{X}$ & - & - \\
\hline Food frequency questionnaire & $\mathrm{X}$ & $\mathrm{X}$ & - & - \\
\hline Material lifestyle & $\mathrm{X}$ & $\mathrm{X}$ & - & - \\
\hline Health care choices & - & - & $\mathrm{X}$ & - \\
\hline Stress & - & - & $\mathrm{X}$ & - \\
\hline Social support and conflict & - & - & $\mathrm{X}$ & - \\
\hline Health locus of control & - & - & $\mathrm{X}$ & - \\
\hline Self-efficacy & - & - & $\mathrm{X}$ & - \\
\hline Food and water insecurity & - & - & $\mathrm{X}$ & - \\
\hline Sleep & - & - & $\mathrm{X}$ & - \\
\hline Body image & - & - & $X$ & - \\
\hline
\end{tabular}




\begin{tabular}{lllll}
\hline Measures & 2010 & $\begin{array}{l}\text { Home visit, 2017- } \\
2019\end{array}$ & $\begin{array}{l}\text { Laboratory visit, 2017- } \\
2019\end{array}$ & $\begin{array}{l}\text { Fat biopsy visit, } \\
2019\end{array}$ \\
\hline Weight stigma and attitudes & - & - & $\mathrm{X}$ & - \\
Weight control behaviors & - & - & $\mathrm{X}$ & - \\
Dietary preferences & - & - & $\mathrm{X}$ & - \\
Living with diabetes & - & - & $\mathrm{X}$ & - \\
Bone and muscle function & - & - & $\mathrm{X}$ & $\mathrm{X}$ \\
Buttock fat biopsy & - & - & - & - \\
\hline
\end{tabular}

andicates that the measure was completed.

${ }^{b}$ Indicates that the measure was not collected at the specific visit.

${ }^{\mathrm{c}}$ BIA: bioelectrical impedance analysis.

${ }^{\mathrm{d}}$ DXA: dual-energy x-ray absorptiometry.

${ }^{\mathrm{e}} \mathrm{HbA}_{1 \mathrm{c}}$ : glycated hemoglobin.

fOGTT: oral glucose tolerance test.

${ }^{\mathrm{g}}$ Questionnaire measures are described in detail in Table 2.

${ }^{\mathrm{h}}$ An abbreviated health history was collected for the purposes of additional eligibility screening before the buttock fat biopsy.

\section{Body Size and Body Composition}

Protocols used in 2010 for the collection of anthropometric data were replicated during the 2017-2019 follow-up study [14]. Weight and height were measured in duplicate to the nearest $0.1 \mathrm{~kg}$ and $0.1 \mathrm{~cm}$, respectively, using a digital weighing scale (Tanita HD 351; Tanita Corporation of America) and a portable stadiometer (SECA 213, Seca GmbH \& Co). Circumferences (midupper arm, abdomen [at the level of the umbilicus], hip, and midcalf) and skinfold thicknesses (forearm, tricep, subscapular, abdominal, and suprailiac; Lange calipers, Beta Technology Inc) were also measured in duplicate to the nearest $0.1 \mathrm{~mm}$. Measurements exceeding the maximum capacity of the skinfold calipers $(>65 \mathrm{~mm}$ ) were recorded as doing so in participant records. Bioelectrical impedance analysis (BIA) measures of resistance and reactance were obtained with an RJL BIA-101Q device (RJL Systems) in all participants without metal implants or pacemakers, using standard procedures. These data will be used to estimate fat mass and body fat percentage.

Whole body and regional body composition were also assessed using dual-energy x-ray absorptiometry (DXA; Lunar iDXA, Encore version 17, General Electric (GE) Healthcare Medicine). Additional eligibility criteria were applied to this assessment; participants did not undergo a DXA scan if they had been exposed to additional $\mathrm{x}$-ray or computed tomography scans in the past 12 months (with the exception of dental x-rays). All women of childbearing age ( $<55$ years) were tested for pregnancy before completing the DXA scan. Participants wore standardized clothing, without metal inserts or buttons, for a total body scan administered by 1 of 4 trained DXA operators in standard or thick mode. Body composition outcomes of interest were fat mass, lean mass, and visceral fat mass and volume (estimated using the CoreScan application, GE Healthcare Medicine). In cases where the participant's body size exceeded the limits of the scan area, participants were placed on the scanning bed such that the first scan captured the limbs on one side of the body and as much of the trunk region as possible. Participants were then repositioned to scan the remaining half of the body. Analyses in these cases will proceed using a mirror mode, where total body composition will be estimated from one half of the body. Among obese adults in other settings, this technique results in nonsignificant differences between mirrored and standard scan data [21].

DXA was also used to assess the bone mineral density and bone mineral content of the whole body, lumbar spine, nondominant hip, and forearm. Bone geometry at the femoral neck was estimated using Hip Structural Software (GE Healthcare Medicine) to calculate section modulus (bone resistance to bending), cross-sectional area, cross-sectional moment of inertia, and minimal neck width.

\section{Blood Pressure and Hand Grip Strength}

After a 10-min seated rest period, blood pressure and heart rate were measured 3 times, with a 3-min rest period between measurements, using an Omron HEM-907XL automated blood pressure monitor (Omron Healthcare). Hand grip strength was assessed as a functional measure of overall strength. After adjusting the handle position of a Jamar Plus+ digital hand dynamometer (Patterson Medical) according to participants' optimal comfort, maximal grip strength was measured in triplicate for both hands with 30 -second rest periods between measurements. Procedures recommended by the American Society of Hand Therapists were followed for standardization [22].

\section{Biospecimen Collection}

Point-of-care testing devices requiring fingerstick blood samples were used to measure hemoglobin (for assessment of anemia; AimStrip $\mathrm{Hb}$ test system, Germaine Laboratories Inc) and glycated hemoglobin $\left(\mathrm{HbA}_{1 c}\right.$; DCA vantage analyzer, Siemens Healthcare $\mathrm{GmbH}) . \mathrm{HbA}_{1 \mathrm{c}}$ values were used to determine if an oral glucose tolerance test (OGTT) could be administered safely: if $\mathrm{HbA}_{1 \mathrm{c}}$ was $\geq 9.0 \%$, participants did not complete the OGTT, and if $\mathrm{HbA}_{1 \mathrm{c}}$ was $\geq 6.5 \%$ (indicating diabetes) but $<9.0 \%$, fasting blood glucose (FBG) was also measured (Bayer Contour Next, 
Bayer HealthCare LLC) and only participants with FBG $<200$ $\mathrm{mg} / \mathrm{dL}$ were allowed to complete the OGTT.

All participants completed a fasting blood draw, where Samoan phlebotomists collected whole blood for serum separation, DNA extraction, and RNA expression (using PaxGene (R) Blood RNA vacutainers, PreAnalytiX GmbH). Participants who could safely complete the 2-hour $75 \mathrm{~g}$ OGTT followed protocols recommended for diabetes diagnosis by the American Diabetes Association [23]. Additional whole blood was collected at 30-min intervals throughout the 2-hour protocol (30-, 60-, 90-, and 120-min postglucose load). Serum from the fasting samples and OGTT draws was separated by centrifugation and stored at $-80^{\circ} \mathrm{C}$ before transport on dry ice to the University of Pittsburgh for analysis. Fasting samples are currently being analyzed for glucose, insulin, free fatty acids, lipid levels (total-, high density lipoprotein, low density lipoprotein, and very low density lipoprotein cholesterol, triglycerides), adiponectin, leptin, and markers of liver function (alanine amino transferase and aspartate aminotransferase). Glucose, insulin, and free fatty acids are being measured in all postglucose load samples.

Whole blood samples for DNA extraction were processed to the cell lysate stage using red blood cell lysis, protein precipitation, and cell lysis solutions following manufacturers protocols (5Prime T-MArchivePure TM, Thermo Fisher Scientific) and shipped at room temperature to the University of Cincinnati where further extraction steps were completed. PAXgene (R) vacutainers were chosen to collect whole blood samples for RNA expression because of their stability during transportation and storage. However, after the initiation of this protocol we learned of United States' import restrictions on the vacutainer reagents, meaning that processing had to be completed at the Samoan site. After storage at $-80^{\circ} \mathrm{C}$, samples were thawed and incubated at room temperature for up to 24 hours. RNA was isolated using the PAXgene (R) blood miRNA kit (PreAnalytix) according to the manufacturer's protocol with the following modification: step 5 of the Qiagen protocol stipulates, "Pipet the sample into a $1.5 \mathrm{ml}$ microcentrifuge tube. Add $300 \mu \mathrm{l}$ Buffer BM2 and $40 \mu \mathrm{l}$ proteinase K. Mix by vortexing for $5 \mathrm{~s}$, and incubate for $10 \mathrm{~min}$ at $55^{\circ} \mathrm{C}$ in a shaker incubator at 400-1400 rpm." A shaker incubator was unavailable for this step; so, after the addition of proteinase $\mathrm{K}$, samples were incubated for $5 \mathrm{~min}$ at $55^{\circ} \mathrm{C}$, uncapped, recapped, vortexed, and incubated for another $5 \mathrm{~min}$ at $55^{\circ} \mathrm{C}$. Two elutions of $40 \mu \mathrm{l}$ of buffer BR5 produced a final volume of $80 \mu \mathrm{L}$ RNA. Following isolation, RNA was stored at $-80^{\circ} \mathrm{C}$ before transfer to a GenTegra RNA matrix. RNA was applied to the GenTegra matrices per the manufacturer's protocol, distributing each sample among 2 GenTegra tubes (approximately $40 \mu \mathrm{l}$ each), and dried overnight in a biosafety cabinet by evaporation. Tubes were then capped, stored, and inventoried before transport to the University of Pittsburgh. Recovery of RNA was performed according to the manufacturer's instructions, using the same volume buffer BR5 as was originally added to the matrix.

Random urine specimens were collected and stored for the study biobank. To allow for the later examination of exposure to environmental chemicals, samples were collected in polypropylene containers, and participants were asked not to touch the inside of the specimen cups or cup lids. Urine specific gravity was measured using a handheld digital refractometer (ATAGO, PAS-10S, ATAGO Co. Ltd) to quantify urine dilution. Samples were aliquoted into polypropylene cryovials and stored at $-80^{\circ} \mathrm{C}$ before shipping on dry ice to Brown University.

\section{Questionnaires}

Over the course of the 2 study visits and in the midparticipation phone call, participants responded to questionnaires that documented their individual and household demographic and socioeconomic characteristics, current health status and health history, physical activity, dietary intake, and sleep patterns and symptoms. Participants also completed multiple psychosocial measures, including body image, stress, self-efficacy, and weight control behaviors. All questionnaire measures were chosen based on existing literature linking the concepts measured with obesity, diabetes, or other aspects of cardiometabolic health and well-being. All the questionnaire measures employed are listed in Table 2, with a brief summary of their content and references for the original survey instruments.

All questionnaires were translated into the Samoan language and administered in Samoan by bilingual local research assistants. Data were collected on iPads using Research Electronic Data Capture (REDCap) tools hosted by Yale University [24,25]. Each questionnaire was completed once, either at the home visit or laboratory assessment, with the exception of the 24-hour dietary recalls, which were completed on three occasions - twice in person (at the home and laboratory visits) and once by phone on a randomly selected day between the 2 in-person visits. Recall days were selected to include 2 weekdays and one weekend day, and protocols followed the multiple-pass method recommended by the US Department of Agriculture [26]. The timing of administration of each questionnaire was carefully considered. First, questionnaires that were asked in 2010 were repeated at the first contact with participants to protect against any loss to follow-up that may have occurred between the home and laboratory visits and maximize the longitudinal data available for assessment (weight and height were collected at the first contact for a similar reason). Second, questionnaires that may have triggered alterations in behavior during the period of measurement between visits (such as some of the weight control behavior or body image measures) were only asked at the laboratory visit once monitoring of dietary intake and physical activity were complete. 
Table 2. Soifua Manuia study questionnaire measures completed in 2017-2019.

\begin{tabular}{|c|c|c|c|c|}
\hline Questionnaire & Number of items & Asked in 2010 & Description & References $^{\mathrm{a}}$ \\
\hline Demographic information & 6 & $X^{b}$ & $\begin{array}{l}\text { Basic demographic information including age, } \\
\text { sex, marital status, and education }\end{array}$ & $-^{c}$ \\
\hline Health interview ${ }^{\mathrm{d}}$ & 36 & $\mathrm{X}$ & $\begin{array}{l}\text { Diagnosis with medical conditions (diabetes, hy- } \\
\text { pertension, heart disease, and high cholesterol), } \\
\text { medication use, use of traditional healers, and } \\
\text { self-reported health and weight }\end{array}$ & - \\
\hline Women's health ${ }^{\mathrm{d}}$ & 26 & $\mathrm{X}$ & $\begin{array}{l}\text { Parity, gravidity, age at menarche, menstrual reg- } \\
\text { ularity, contraceptive use, infertility, pregnancy } \\
\text { history, and menopause (age and symptoms) }\end{array}$ & Barkan et al [27] \\
\hline Cigarette and alcohol use & 15 & $\mathrm{X}$ & $\begin{array}{l}\text { Use of tobacco products, alcohol consumption, } \\
\text { and problems with drunkenness }\end{array}$ & - \\
\hline Physical activity & 11 & $\mathrm{X}$ & $\begin{array}{l}\text { Global Physical Activity Questionnaire (GPAQ), } \\
\text { which estimates time spent in moderate-vigorous } \\
\text { work, transport, and leisure-related activities }\end{array}$ & $\begin{array}{l}\text { World Health Orgnaiza- } \\
\text { tion [28] }\end{array}$ \\
\hline Food frequency questionnaire & 111 & $\mathrm{X}$ & $\begin{array}{l}\text { Locally validated food frequency questionnaire } \\
\text { measuring consumption (never or less than once } \\
\text { a month to more than } 6 \text { times per day) and usual } \\
\text { portion size }\end{array}$ & - \\
\hline Material lifestyle $^{\mathrm{d}}$ & 46 & $\mathrm{X}$ & $\begin{array}{l}\text { Household assets inventory, amenities (plumbing, } \\
\text { cooking, and toilet facilities), number of house- } \\
\text { hold residents, occupation of heads of household, } \\
\text { income, village wealth, disparities, and communi- } \\
\text { ty spirit }\end{array}$ & - \\
\hline Health care choices & 17 & - & $\begin{array}{l}\text { Use of and preferences for traditional versus } \\
\text { western biomedical health care practitioners }\end{array}$ & - \\
\hline Stress & 18 & - & $\begin{array}{l}\text { Cohen Perceived Stress Scale (PSS) and Short } \\
\text { Form- } 8 \text { quality of life measures }\end{array}$ & $\begin{array}{l}\text { Cohen et al [29]; Ware et } \\
\text { al [30] }\end{array}$ \\
\hline Social support and conflict & 19 & - & $\begin{array}{l}\text { Multidimensional Scale of Perceived Social Sup- } \\
\text { port (MSPSS) and perceived social conflict }\end{array}$ & $\begin{array}{l}\text { Zimet et al [31]; O'Brien } \\
\text { et al [32] }\end{array}$ \\
\hline Health locus of control & 18 & - & $\begin{array}{l}\text { Beliefs about internal versus external control over } \\
\text { health and well-being }\end{array}$ & Wallston et al [33] \\
\hline Self-efficacy & 35 & - & $\begin{array}{l}\text { General and social self-efficacy and exercise } \\
\text { confidence survey }\end{array}$ & $\begin{array}{l}\text { Sherer et al [34] Clark et } \\
\text { al [35]; Sallis et al [36] }\end{array}$ \\
\hline Food and water insecurity & 52 & - & $\begin{array}{l}\text { Household Food Insecurity Access Scale (HFIAS) } \\
\text { and Household Water Insecurity Experiences scale } \\
\text { (HWISE) }\end{array}$ & $\begin{array}{l}\text { Coates et al [37]; Young } \\
\text { et al [38] }\end{array}$ \\
\hline Sleep & 23 & - & $\begin{array}{l}\text { Sleep duration, sleep quality, chronotype, shift } \\
\text { work, and Epworth Daytime Sleepiness Scale } \\
\text { (EDSS) }\end{array}$ & Bild et al [39]; Johns [40] \\
\hline Body image & 20 & - & $\begin{array}{l}\text { Satisfaction with body shape and size and body } \\
\text { size preferences }\end{array}$ & Brewis et al[41] \\
\hline Weight stigma and attitudes ${ }^{\mathrm{e}}$ & 66 & - & $\begin{array}{l}\text { Attitudes toward obese persons scale, beliefs about } \\
\text { obese people, weight stigma, and discrimination }\end{array}$ & $\begin{array}{l}\text { Allison et al [42]; Myers } \\
\text { and Rosen [43] }\end{array}$ \\
\hline Self-esteem & 19 & - & Rosenberg self-esteem scale & Rosenberg [44] \\
\hline Weight control behaviors & 53 & - & $\begin{array}{l}\text { Eating habits, dietary preferences, and weight } \\
\text { control efforts }\end{array}$ & $\begin{array}{l}\text { Neumark-Sztainer et al } \\
\text { [45] }\end{array}$ \\
\hline Dietary preferences & 50 & - & $\begin{array}{l}\text { Three-factor eating questionnaire (cognitive re- } \\
\text { straint of eating, disinhibition, and hunger) }\end{array}$ & $\begin{array}{l}\text { Stunkard and Messick } \\
\text { [46] }\end{array}$ \\
\hline Living with diabetes ${ }^{\mathrm{f}}$ & 86 & - & $\begin{array}{l}\text { Diabetes symptoms and self-care behaviors, per- } \\
\text { ceived diabetes control, medication adherence, } \\
\text { and beliefs about diabetes }\end{array}$ & $\begin{array}{l}\text { Carey et al [47]; DePue } \\
\text { et al [48] }\end{array}$ \\
\hline Bone and muscle function & 9 & - & $\begin{array}{l}\text { Broken bones, bone-specific supplement use, and } \\
\text { SARC-F screen for sarcopenia }\end{array}$ & Malmstrom et al [49] \\
\hline
\end{tabular}


${ }^{\mathrm{a}}$ References indicate the sources of questionnaire items; questionnaires may not have been used in their entirety and may have been adapted to the Samoan context.

${ }^{\mathrm{b}}$ Indicates that the questionnaire was also completed in 2010.

${ }^{\mathrm{c}}$ Indicates that the measure was not collected in 2010. In the references column, it indicates that questions cannot be attributed to a single source or were of the authors design.

${ }^{\mathrm{d}}$ Some questionnaire items were updated between 2010 and 2017, so not all questions were consistent across time points; health interviews were updated with additional questions about medication adherence and locally available generic medication brands, women's health included more detailed menstrual regularity questions in 2010, and the material lifestyle household assets inventory was updated with newly available household commodities monitored in the Samoa Demographic and Health Survey.

${ }^{\mathrm{e}}$ One section of this questionnaire ( $\mathrm{n}=19$ questions), concerned with experiences of overweight or obesity, was only asked of participants who self-reported being moderately or much too heavy.

${ }^{\mathrm{f}}$ Asked only of those participants who self-reported a diagnosis of type 2 diabetes.

\section{Objective Physical Activity Monitoring}

Actigraph GT3X+ accelerometer-based devices (ActiGraph Corporation) were used to objectively measure physical activity during the 7-10 day period between the home and laboratory visits. The GT3X+ was secured to the nondominant wrist using a disposable hospital band. The wrist placement was chosen for several reasons: (1) for continuous monitoring that would allow assessment of sleep patterns, (2) to better accommodate Samoan clothing styles (as compared with waist-worn), and (3) to prevent loss of the devices and minimize missing data associated with participants forgetting to replace their device after removing with clothing or bathing. The GT3X+ devices were initialized to collect raw acceleration at $30 \mathrm{~Hz}$, and participants were asked to wear the devices continuously until the laboratory visit. Devices were removed at the laboratory visit, where data were downloaded and briefly reviewed for completeness. In the event that less than 5 days of data were recorded, participants were asked to repeat the assessment. Expected output from the objective physical activity monitoring includes estimates of daily energy expenditure (metabolic equivalents); daily steps; sedentary time; and time spent in light, moderate, and vigorous physical activity.

\section{Sleep Apnea Detection}

We provided 391 participants with a WatchPAT TM 200 Unified (Itamar Medical Ltd.) device, consisting of a finger probe and chest sensor to evaluate sleep apnea and sleep patterns (devices became available several months into the recruitment period, after which all participants completed this assessment). The WatchPAT TM was worn on the nondominant wrist (proximal to the GT3X+, so results could be compared) the night before the laboratory visit. The device measured peripheral arterial tone (PAT TM) signal, oxygen saturation, actigraphy, acoustic decibels (snoring evaluation), and body position. The output was downloaded to a computer, encrypted, and sent to collaborators at Brigham and Women's/Harvard Medical School for interpretation. Sleep studies were reviewed within 48 hours of receipt by expert analysts, and all participants with readings indicative of severe sleep apnea $(n=15)$ were referred to a local sleep clinic in Apia.

\section{Buttock Fat Biopsies}

At the time of consent for the overall study, participants were asked to consent separately to completing a subcutaneous buttock fat biopsy so that the effect of the $C R E B R F$ variant on gene expression in adipose tissue could be determined. To limit variation by disease status, we selected a subsample of participants to recontact and ask to participate in this additional procedure. The participants in this subset were those without diabetes (those without a self-reported diabetes diagnosis at the time of participation in the main protocol and those with $\mathrm{HbA}_{1 \mathrm{c}}$ $<6.5 \%$ ), cancer, or cardiovascular disease. For convenience and efficiency, we sampled participants within a 45-min drive of the AUA. Participants were recontacted either by phone or at their homes during a 2-week period in January 2019. Given the genotype frequencies and diabetes prevalence in the population, we aimed to recruit 26 nondiabetic women and 15 nondiabetic men for each of the 3 genotypes (AA, AG, and GG). Participants were rescreened for the overall study eligibility criteria (pregnancy, lactation, birth within 6 months, and major weight loss) as well as the specific biopsy criteria, including additional point-of-care $\mathrm{HbA}_{1 \mathrm{c}}$ measurement, in their homes. Willing and eligible participants were then scheduled for the biopsy procedure.

Biopsies were completed in a sterile environment at a local medical facility. After the procedure, an adapted version of that described by Beynen and Katan [50] was explained in detail by the study clinician (A Prescott, plastic surgery resident), and additional verbal consent to the procedure was obtained in the Samoan language by study staff. Participants lay in a prone position with the left gluteal soft tissue exposed. Using red light technology, a commercial vein identification device (Illumivein, Easy-RN LLC) was used to identify any venous plexuses in the subcutaneous tissues. The anticipated biopsy site (with the least amount of subcutaneous vessels) was marked with a surgical skin marker, and an ice pack was applied for 1 min to numb the area. The skin was prepped with single-use sterile ChloraPrep (TM; Becton, Dickinson and Company), allowed to dry, and topical Gebauer's ethyl chloride spray was used to anesthetize the anticipated biopsy site. Participants were asked to contract their gluteal muscles, while the clinician performed a pinch test (using single-use, latex-free, sterile gloves) on the anticipated biopsy site. A single-use, sterile 16-gauge needle attached to a single-use, sterile $1 \mathrm{cc}$ syringe was inserted into the biopsy site percutaneously to harvest the adipose tissue samples. Using a handheld aspiration technique (applying gentle negative manual pressure to the syringe or needle apparatus), 10-30 passes were performed at a 45-degree angle, until adipose tissue was visibly seen in the syringe. In cases where the study participant demonstrated more than minimal discomfort (or if samples were too sanguineous), the biopsy was terminated immediately. Once the lipoaspirate was visible in the syringe, the needle or syringe 
was completely removed from the biopsy site and handed off to a technician for downstream processing. When the biopsy site was deemed adequately hemostatic, a small gauze was applied and secured gently with adhesive tape. Study participants were observed for up to $60 \mathrm{~min}$ before departing the study site. Study participants were provided with postbiopsy care instructions and a contact number to call if any unusual or severe adverse effects were encountered.

Following sample collection, the syringe containing the adipose sample was washed with 0.5-1 ml RNALater (R; Ambion Inc). The mixture of RNALater (R) and lipoaspirate was then expelled into a $1.55-\mathrm{ml}$ microcentrifuge tube and incubated at $5^{\circ} \mathrm{C}$ overnight before transfer to $-80^{\circ} \mathrm{C}$ the next day per the manufacturer's protocol. Samples in RNALater (R) were transported from Apia, Samoa, to the University of Pittsburgh. Although samples in RNALater (R) are stable for up to a week at room temperature, we shipped the samples on ice, with refrigeration and/or refreshed ice between destinations, to maintain a more consistent temperature as temperatures can fluctuate dramatically across climates and altitudes. Upon arrival in Pittsburgh, samples were stored at $-80^{\circ} \mathrm{C}$ until processing. To process, frozen samples were thawed at room temperature, and RNALater $(\mathrm{R})$ was removed from the sample by straining the RNALater $(\mathrm{R})+$ lipoaspirate through a $0.22-\mu \mathrm{m}$ nylon cell strainer placed atop a 50- $\mathrm{ml}$ conical tube (such that the sample was collected in the strainer and the RNALater was collected in the conical tube). The strainer was weighed before and after the sample was strained to acquire the mass of the lipoaspirate. The tissue was then collected from the strainer into a 14-ml round bottom tube containing $1 \mathrm{ml}$ of QIAzol Lysis Reagent (Qiagen Sciences Inc) and homogenized for 30 seconds with a TissueRuptor (R; Qiagen Sciences Inc). Following homogenization, total RNA was isolated from the homogenate using RNeasy Lipid Tissue Mini Kit (R; also Qiagen) according to the manufacturer's protocol, including optional DNase treatment to remove contaminating genomic DNA and optional full speed spin to remove residual buffer RPE or flow-through. Two elutions of $30-\mu 1$ nuclease-free water were used in the final step for a final volume of $60 \mu \mathrm{l}$ RNA.

\section{Participant Feedback and Referrals to Clinical Services}

Participant feedback occurred in several stages. First, at the completion of the laboratory visit, all participants received a feedback sheet that used a traffic light (green, orange, and red) approach to describe their risk of overweight or obesity, anemia, hypertension, and diabetes (based on $\mathrm{HbA}_{1 \mathrm{c}}$ ) as well as recommendations for further follow-up screening and behavioral modifications based on those risks. After serum analyses were completed, participants received individual letters with their cholesterol, triglycerides, fasting glucose, and insulin, and OGTT results as well as a study summary, which described key findings from the overall study and provided village and like-for-like comparisons to allow participants to put their individual results in context (eg, men $<40$ years of age were provided with summary data for all men in their comparable age range). At both stages, study staff provided referrals to local clinical services where participants met local risk criteria for diabetes, hypertension, or anemia. Participants are able to engage with study progress via the study's Facebook page (@YaleOlaga), and the private message function on the page offered an additional way for participants to contact study staff with questions about their participation (study staff could also be contacted by phone or text message).

\section{Data Management and Statistical Analysis}

Descriptive analyses will first be used to characterize the metabolic and behavioral traits of participants. Questionnaire measures that have not previously been validated in the Samoan setting will be examined for validity and internal consistency before analyses proceed. Then, we will test for cross-sectional associations of measured traits with the CREBRF variant using methods appropriate for the categorical or continuous nature of the outcomes, while adjusting for relevant covariates including age, sex, and relatedness. While many of our analyses using the newly collected data will initially be hypothesis-free, we will continue to be informed by our parallel mouse and cell models and test the resulting hypotheses using methods appropriate to the questions being addressed. Longitudinal analyses, where there are comparable measures available from the 2010 data collection (eg, weight or BMI) will use appropriate linear-mixed models that explicitly model the dependence between the different time points. After quality control and data cleaning are completed, the cleaned datasets generated during this study will be available in the $\mathrm{dbGaP}$ repository under the accession number phs000914 [20].

\section{Results}

The study was funded by the US National Institutes of Health (R01HL093093) in March 2016. Data collection was completed among 519 participants between July 2017 and March 2019, and results addressing the main study hypotheses are expected to be published in 2020 and 2021.

\section{Discussion}

\section{Significance}

Although the genetic variant rs373863828, in CREBRF, has the largest known effect size of any identified obesity gene, very little is currently understood about the mechanisms by which it confers increased odds of obesity but paradoxically lowered odds of type 2 diabetes. A small number of studies have evaluated the CREBRF gene (not this variant specifically) in nonhuman preclinical models. These studies have implicated $C R E B R F$ in a variety of disparate cellular and physiological processes, including the unfolded protein response [51], glucocorticoid signaling and maternal behaviors [52], reproduction [53,54], viral pathogenesis [55], angiogenesis [56], carcinogenesis [57,58], and starvation resistance [59]. However, this protocol is the first attempt to broadly characterize the association of the variant with a wide variety of metabolic and behavioral traits in humans.

Overweight, obesity, and type 2 diabetes-the complex and chronic conditions that are the focus of this protocol-are major health concerns that are estimated to cause 3.4 million deaths, $4 \%$ of years of life lost, and $4 \%$ of disability-adjusted life years in high-, low-, and middle-income countries [60]. Every effort 
must be made to understand the basic biological underpinnings of these complex, chronic conditions, so that appropriate pathways may be targeted by behavioral and pharmacologic intervention. Although we do not describe our additional ongoing studies here, the activities described in this protocol occurred alongside additional cell and mouse studies, including characterization of the gene networks mediating the effects of the variant on energy and metabolic homeostasis. We will also seek to identify the role of natural selection in the emergence of the CREBRF variant and other variants coselected with it that may contribute to its risk.

\section{Strengths and Limitations}

Although we believe the approach we have described has the potential to generate new understanding of the genetic basis of obesity and diabetes risk in this population, it is not without limitations. Although several key analyses will be able to take advantage of longitudinal data, many of the phenotypes collected here were measured for the first time in the cohort in 2017-2019, meaning analyses will be cross-sectional and we will have limited ability to infer causality. Several of our measurement tools, particularly those used to measure behavioral traits, were new to the Samoan setting, and despite rigorous protocols for translation and staff training, will require testing for validity and reliability in this population. Most significant though are potential biases in our sampling, stemming from both our initial sampling strategy in the 2010 GWAS study, where a nonrepresentative convenience sampling approach was used, and our selective follow-up of only Upolu residents (necessitated by the near-impossibility of transporting the DXA scanner to the most rural residents of Savai'i). Our nonrepresentational sampling, with strong oversampling of AAs and moderate oversampling of AGs, ensures that we have enough individuals with the rarer genotypes to be able to contrast them against the common GGs. However, it is important to consider the possible effects of the initial matching on sex, age within 5 years, and census region, followed by looser matching; this sampling strategy, which may induce bias, reflects the realities and complexities of fieldwork. Kuo et al [61] found that matching in loose-matching data can be ignored for negligible loss in testing and estimation if the distributions of matching variables are not extremely different between cases and controls. To examine this in our own data, we simulated 20,000 replicates of a quantitative trait in the whole sample gathered in 2010 as a function of each individual's observed values for age, sex, rs373863828 genotype (coded 0,1,2), census region, and random normal $\mathrm{N}(0,1)$ noise and assumed true effect sizes; the effect size of the genotype was set such that its mean $P$ value was 2.7 $\times 10^{-6}$ in the larger 2010 sample. Then, we subset the data to the 519 individuals who are in our current sample and examined the percent bias in the estimates of the regression parameters derived ignoring matching. Similar to Kuo et al's results [61], we find that the bias in the estimates is very small, for example, for the genotype effect size estimate, which is of primary interest, the bias is only $-0.43 \%$. Although more extensive simulations are merited, it appears that our sampling strategy does not induce strong bias in the estimates relative to their true population-level values. The estimated power in the 519 selected individuals to detect association of the simulated trait with genotype, while adjusting for the other predictors, at the .01 level was $82.8 \%$. This is in line with earlier simulations done when we initially sought funding for this work where we found that, based on simulated sampling from the total set of the 2010 participants, we should have $87.1 \%$ power at the 0.01 level to detect our BMI signal and $78.4 \%$ power for hip circumference.

This study lays the groundwork for subsequent analysis to understand how the $C R E B R F$ risk variant influences adiposity and cardiometabolic traits. These studies, in combination with studies to understand the CREBRF gene more generally, are expected to be significant because they are likely to reveal entirely new pathways upstream and downstream of $C R E B R F$ that more broadly influence energy and metabolic traits across multiple populations and ethnic groups and individuals. Such knowledge could provide novel targets to prevent or treat obesity, diabetes, and associated metabolic disorders. This study represents the human arm of a comprehensive and integrated approach involving humans as well as preclinical models that will provide novel insights into metabolic disease.

\section{Acknowledgments}

The authors would like to acknowledge and sincerely thank the research participants, the Samoan government, particularly the Ministry of Health, Ministry of Women, Community, and Social Development; the Office of the Prime Minister; and the Samoa Bureau of Statistics for their continued support of this work. The authors would like to thank Pavane Gorrepati, Becca Levy, Alex Brewis, Lynette Leidy-Sievert, and Sera Young for their assistance in questionnaire development. The authors would also like to thank Itamar Medical Ltd for their loan of the devices used for sleep monitoring and Alec Ekeroma for his assistance with the fat biopsy procedures. This study was supported by a US National Institutes of Health (NIH) grant R01HL093093 (Principal Investigator [PI]: Stephen McGarvey, Brown University) and UL1TR001857 (PI: Steven E Reis, University of Pittsburgh). AR was supported by the US NIH and Fogarty International Center (Global Health Equity Scholars program D43TW010540) and the NIH National Institute of Diabetes and Digestive and Kidney Diseases. S Rosenthal was supported by the US NIH grant T32CA175294 (PI: John M. Kirkwood, University of Pittsburgh). S To was supported by a Downs International Health Student Travel Fellowship. SR and analysis of the sleep data were supported by NIH R35HL135818. The funding sources had no role in the design or conduct of the study; collection, management, analysis, and interpretation of the data; preparation, review, or approval of the manuscript; or the decision to submit this manuscript for publication.

\section{Conflicts of Interest}

None declared. 


\section{References}

1. Lin S, Naseri T, Linhart C, Morrell S, Taylor R, McGarvey ST, et al. Trends in diabetes and obesity in Samoa over 35 years, 1978-2013. Diabet Med 2017 May;34(5):654-661 [FREE Full text] [doi: 10.1111/dme.13197] [Medline: 27505623]

2. $\mathrm{Ng} \mathrm{M}$, Fleming T, Robinson M, Thomson B, Graetz N, Margono C, et al. Global, regional, and national prevalence of overweight and obesity in children and adults during 1980-2013: a systematic analysis for the global burden of disease study 2013. Lancet 2014 Aug 30;384(9945):766-781 [FREE Full text] [doi: 10.1016/S0140-6736(14)60460-8] [Medline: 24880830]

3. NCD Risk Factor Collaboration (NCD-RisC). Trends in adult body-mass index in 200 countries from 1975 to 2014 : a pooled analysis of 1698 population-based measurement studies with 19.2 million participants. Lancet $2016 \mathrm{Apr}$ 2;387(10026):1377-1396 [FREE Full text] [doi: 10.1016/S0140-6736(16)30054-X] [Medline: 27115820]

4. Seiden A, Hawley NL, Schulz D, Raifman S, McGarvey ST. Long-term trends in food availability, food prices, and obesity in Samoa. Am J Hum Biol 2012;24(3):286-295 [FREE Full text] [doi: 10.1002/ajhb.22237] [Medline: 22371334]

5. Minster RL, Hawley NL, Su C, Sun G, Kershaw EE, Cheng H, et al. A thrifty variant in CREBRF strongly influences body mass index in Samoans. Nat Genet 2016 Sep;48(9):1049-1054 [FREE Full text] [doi: 10.1038/ng.3620] [Medline: 27455349]

6. Loos RJ, Yeo GS. The bigger picture of FTO: the first GWAS-identified obesity gene. Nat Rev Endocrinol 2014 Jan;10(1):51-61 [FREE Full text] [doi: 10.1038/nrendo.2013.227] [Medline: 24247219]

7. Naka I, Furusawa T, Kimura R, Natsuhara K, Yamauchi T, Nakazawa M, et al. A missense variant, rs373863828-A (p.Arg457Gln), of CREBRF and body mass index in Oceanic populations. J Hum Genet 2017 Sep;62(9):847-849. [doi: 10.1038/jhg.2017.44] [Medline: 28405013]

8. Berry SD, Walker CG, Ly K, Snell RG, Carr PE, Bandara D, et al. Widespread prevalence of a CREBRF variant amongst Māori and Pacific children is associated with weight and height in early childhood. Int J Obes (Lond) 2018 Apr;42(4):603-607. [doi: 10.1038/ijo.2017.230] [Medline: 28928463]

9. Krishnan M, Major TJ, Topless RK, Dewes O, Yu L, Thompson JM, et al. Discordant association of the CREBRF rs373863828 A allele with increased BMI and protection from type 2 diabetes in Māori and Pacific (Polynesian) people living in Aotearoa/New Zealand. Diabetologia 2018 Jul;61(7):1603-1613 [FREE Full text] [doi: 10.1007/s00125-018-4623-1] [Medline: 29721634]

10. Ohashi J, Naka I, Furusawa T, Kimura R, Natsuhara K, Yamauchi T, et al. Association study of CREBRF missense variant (rs373863828:G > A; p.Arg457Gln) with levels of serum lipid profile in the Pacific populations. Ann Hum Biol 2018 May;45(3):215-219. [doi: 10.1080/03014460.2018.1461928] [Medline: 29877158]

11. Hanson RL, Safabakhsh S, Curtis JM, Hsueh W, Jones LI, Aflague TF, et al. Association of CREBRF variants with obesity and diabetes in Pacific islanders from Guam and Saipan. Diabetologia 2019 Sep;62(9):1647-1652. [doi: 10.1007/s00125-019-4932-z] [Medline: $\underline{31280340]}$

12. Karczewski K, Francioli L, Tiao G, Cummings B, Alföldi J, Wang Q, The Genome Aggregation Database Consortium, et al. Variation across 141,456 human exomes and genomes reveals the spectrum of loss-of-function intolerance across human protein-coding genes. bioRxiv 2019 preprint [FREE Full text] [doi: 10.1101/531210]

13. BRAVO variant browser: University of Michigan and NHLBI. 2018. The NHLBI Trans-Omics for Precision Medicine (TOPMed) Whole Genome Sequencing Program URL: https://bravo.sph.umich.edu/freeze5/hg38 [accessed 2020-04-22]

14. Hawley NL, Minster RL, Weeks DE, Viali S, Reupena MS, Sun G, et al. Prevalence of adiposity and associated cardiometabolic risk factors in the Samoan genome-wide association study. Am J Hum Biol 2014;26(4):491-501 [FREE Full text] [doi: 10.1002/ajhb.22553] [Medline: 24799123]

15. Samoa Bureau of Statistics. 2017. 2016 Census Brief No 1: Revised version. Population Snapshot and Household Highlights URL: https://www.sbs.gov.ws/digi/2016 Census Brief No.1.pdf [accessed 2020-04-22]

16. World Bank Open Data. 2019. Country Information: Samoa URL: https://data.worldbank.org/country/samoa [accessed 2019-08-22]

17. United Nations Development Programme. Human Development Report 2016: Human Development for Everyone. New York, NY: UNDP; 2016.

18. World Health Organization. 2019. Country Information: Samoa URL: https://www.who.int/countries/wsm/en/ [accessed 2019-08-29]

19. Aulchenko YS, Ripke S, Isaacs A, van Duijn CM. GenABEL: an R library for genome-wide association analysis. Bioinformatics 2007 May 15;23(10):1294-1296. [doi: 10.1093/bioinformatics/btm108] [Medline: 17384015]

20. NCBI - NIH. The Database of Genotypes and Phenotypes (dbGaP). Genome-wide Association Study of Adiposity in Samoans URL: https://www.ncbi.nlm.nih.gov/projects/gap/cgi-bin/study.cgi?study_id=phs000914.v1.p1 [accessed 2020-04-20]

21. Rothney MP, Brychta RJ, Schaefer EV, Chen KY, Skarulis MC. Body composition measured by dual-energy X-ray absorptiometry half-body scans in obese adults. Obesity (Silver Spring) 2009 Jun;17(6):1281-1286 [FREE Full text] [doi: 10.1038/oby.2009.14] [Medline: 19584885]

22. MacDermid J, Solomon G, Fedorczyk J, Valdes K. Impairment based conditions. In: Clinical Assessment Recommendations. Third Edition. Mount Laurel, NJ: American Society of Hand Therapists; 2015. 
23. American Diabetes Association. Classification and diagnosis of diabetes: standards of medical care in diabetes-2018. Diabetes Care 2017 Dec 8;41(Supplement 1):S13-S27. [doi: 10.2337/dc18-s002] [Medline: 29222373]

24. Harris PA, Taylor R, Thielke R, Payne J, Gonzalez N, Conde JG. Research electronic data capture (REDCap)-a metadata-driven methodology and workflow process for providing translational research informatics support. J Biomed Inform 2009 Apr;42(2):377-381 [FREE Full text] [doi: 10.1016/j.jbi.2008.08.010] [Medline: 18929686]

25. Harris PA, Taylor R, Minor BL, Elliott V, Fernandez M, O'Neal L, REDCap Consortium. The REDCap consortium: building an international community of software platform partners. J Biomed Inform 2019 Jul;95:103208. [doi: 10.1016/j.jbi.2019.103208] [Medline: 31078660]

26. Moshfegh A, Rhodes D, Baer DJ, Murayi T, Clemens J, Rumpler W, et al. The US department of agriculture automated multiple-pass method reduces bias in the collection of energy intakes. Am J Clin Nutr 2008 Aug;88(2):324-332. [doi: 10.1093/ajcn/88.2.324] [Medline: 18689367$]$

27. Barkan SE, Melnick SL, Preston-Martin S, Weber K, Kalish LA, Miotti P, et al. The women's interagency HIV study. WIHS collaborative study group. Epidemiology 1998 Mar;9(2):117-125. [doi: 10.1097/00001648-199803000-00004] [Medline: 9504278]

28. World Health Organization. Global Physical Activity Questionnaire (GPAQ). WHO STEPwise Approach to NCD Risk Factor Surveillance URL: https://www.who.int/ncds/surveillance/steps/GPAQ_EN.pdf [accessed 2019-11-25]

29. Cohen S, Kamarck T, Mermelstein R. A global measure of perceived stress. J Health Soc Behav 1983 Dec;24(4):385-396. [doi: 10.2307/2136404] [Medline: $\underline{6668417}$ ]

30. Ware J, Kosinski M, Dewey J, Gandek B. How to Score and Interpret Single-item Health Status Measures: A Manual for Users of the of the SF-8 Health Survey : (with a Supplement on the SF-6 Health Survey). Boston, MA: QualityMetric; 2001.

31. Zimet GD, Dahlem NW, Zimet SG, Farley GK. The multidimensional scale of perceived social support. J Pers Assess 1988 Mar;52(1):30-41. [doi: 10.1207/s15327752jpa5201 2]

32. O'Brien K, Wortman CB, Kessler RC, Joseph JG. Social relationships of men at risk for AIDS. Soc Sci Med 1993 May;36(9):1161-1167. [doi: 10.1016/0277-9536(93)90236-w] [Medline: $\underline{\text { 8511645] }}$

33. Wallston KA, Wallston BS, DeVellis R. Development of the multidimensional health locus of control (MHLC) scales. Health Educ Monogr 1978;6(2):160-170. [doi: 10.1177/109019817800600107] [Medline: 689890]

34. Sherer M, Maddux JE, Mercandante B, Prentice-Dunn S, Jacobs B, Rogers RW. The self-efficacy scale: construction and validation. Psych Rep 1982;51(2):663-671. [doi: 10.2466/pr0.1982.51.2.663]

35. Clark MM, Abrams DB, Niaura RS, Eaton CA, Rossi JS. Self-efficacy in weight management. J Consult Clin Psych 1991;59(5):739-744. [doi: 10.1037/0022-006x.59.5.739] [Medline: 1955608]

36. Sallis JF, Pinski RB, Grossman RM, Patterson TL, Nader PR. The development of self-efficacy scales for health-related diet and exercise behaviors. Health Educ Res 1988 Nov;3(3):283-292. [doi: 10.1093/her/3.3.283]

37. Coates J, Swindale A, Bilinsky P. Food and Nutrition Technical Assistance III Project (FANTA). 2007. Household Food Insecurity Access Scale (HFIAS) for Measurement of Food Access: Indicator Guide URL: https://www.fantaproject.org/ monitoring-and-evaluation/household-food-insecurity-access-scale-hfias [accessed 2020-04-24]

38. Young SL, Boateng GO, Jamaluddine Z, Miller JD, Frongillo EA, Neilands TB, HWISE Research Coordination Network. The Household Water Insecurity Experiences (HWISE) Scale: development and validation of a household water insecurity measure for low-income and middle-income countries. BMJ Glob Health 2019;4(5):e001750 [FREE Full text] [doi: 10.1136/bmjgh-2019-001750] [Medline: 31637027]

39. Bild D, Bluemke D, Burke G, Detrano R, Roux AV, Folsom AR, et al. Multi-ethnic study of atherosclerosis: objectives and design. Am J Epidemiol 2002 Nov 1;156(9):871-881. [doi: 10.1093/aje/kwf113] [Medline: 12397006]

40. Johns M. A new method for measuring daytime sleepiness: the Epworth sleepiness scale. Sleep 1991 Dec;14(6):540-545. [doi: 10.1093/sleep/14.6.540] [Medline: 1798888]

41. Brewis A, McGarvey S, Jones J, Swinburn B. Perceptions of body size in Pacific islanders. Int J Obes Relat Metab Disord 1998 Feb;22(2):185-189. [doi: 10.1038/sj.ijo.0800562] [Medline: 9504327]

42. Allison D, Basile V, Yuker H. The measurement of attitudes toward and beliefs about obese persons. Int J Eat Disord 1991;10:599-607. [doi: 10.1002/1098-108X(199109)10:5<599::AID-EAT2260100512>3.0.CO;2-\%23]

43. Myers A, Rosen J. Obesity stigmatization and coping: relation to mental health symptoms, body image, and self-esteem. Int J Obes Relat Metab Disord 1999 Mar;23(3):221-230. [doi: 10.1038/sj.ijo.0800765] [Medline: 10193866]

44. Rosenberg M. Society and the Adolescent Self-Image. Princeton, NJ: Princeton University Press; 1965.

45. Neumark-Sztainer D, Hannan PJ, Story M, Perry CL. Weight-control behaviors among adolescent girls and boys: implications for dietary intake. J Am Diet Assoc 2004 Jun;104(6):913-920. [doi: 10.1016/j.jada.2004.03.021] [Medline: 15175589]

46. Stunkard AJ, Messick S. The three-factor eating questionnaire to measure dietary restraint, disinhibition and hunger. $\mathrm{J}$ Psychosom Res 1985;29(1):71-83. [doi: 10.1016/0022-3999(85)90010-8] [Medline: 3981480]

47. Carey MP, Jorgensen RS, Weinstock RS, Sprafkin RP, Lantinga LJ, Carnrike CL, et al. Reliability and validity of the appraisal of diabetes scale. J Behav Med 1991 Feb;14(1):43-51. [doi: 10.1007/bf00844767] [Medline: 2038044] 
48. de Pue JD, Dunsiger S, Seiden AD, Blume J, Rosen RK, Goldstein MG, et al. Nurse-community health worker team improves diabetes care in American Samoa: results of a randomized controlled trial. Diabetes Care 2013 Jul;36(7):1947-1953 [FREE Full text] [doi: 10.2337/dc12-1969] [Medline: 23393217]

49. Malmstrom TK, Miller DK, Simonsick EM, Ferrucci L, Morley JE. SARC-F: a symptom score to predict persons with sarcopenia at risk for poor functional outcomes. J Cachexia Sarcopenia Muscle 2016 Mar;7(1):28-36 [FREE Full text] [doi: 10.1002/jcsm.12048] [Medline: 27066316]

50. Beynen A, Katan M. Rapid sampling and long-term storage of subcutaneous adipose-tissue biopsies for determination of fatty acid composition. Am J Clin Nutr 1985 Aug;42(2):317-322. [doi: 10.1093/ajcn/42.2.317] [Medline: 4025201]

51. Audas TE, Li Y, Liang G, Lu R. A novel protein, Luman/CREB3 recruitment factor, inhibits Luman activation of the unfolded protein response. Mol Cell Biol 2008 Jun;28(12):3952-3966 [FREE Full text] [doi: 10.1128/MCB.01439-07] [Medline: 18391022]

52. Martyn AC, Choleris E, Gillis DJ, Armstrong JN, Amor TR, McCluggage AR, et al. Luman/CREB3 recruitment factor regulates glucocorticoid receptor activity and is essential for prolactin-mediated maternal instinct. Mol Cell Biol 2012 Dec;32(24):5140-5150 [FREE Full text] [doi: 10.1128/MCB.01142-12] [Medline: 23071095]

53. Yang Y, Jin Y, Martyn AC, Lin P, Song Y, Chen F, et al. Expression pattern implicates a potential role for Luman recruitment factor in the process of implantation in uteri and development of preimplantation embryos in mice. J Reprod Dev 2013;59(3):245-251 [FREE Full text] [doi: 10.1262/jrd.2012-137] [Medline: 23400243]

54. Yang D, Jiang T, Liu J, Zhang B, Lin P, Chen H, et al. CREB3 regulatory factor-mTOR-autophagy regulates goat endometrial function during early pregnancy. Biol Reprod 2018 May 1;98(5):713-721. [doi: 10.1093/biolre/ioy044] [Medline: 29447354]

55. Audas TE, Hardy-Smith PW, Penney J, Taylor T, Lu R. Characterization of nuclear foci-targeting of Luman/CREB3 recruitment factor (LRF/CREBRF) and its potential role in inhibition of herpes simplex virus-1 replication. Eur J Cell Biol 2016 Dec;95(12):611-622. [doi: 10.1016/j.ejcb.2016.10.006] [Medline: 28029379]

56. Wong N, Cheung H, Solly E, Vanags L, Ritchie W, Nicholls S, et al. Exploring the roles of and in the regulation of angiogenesis by high-density lipoproteins. Int J Mol Sci 2018 Jun 28;19(7):1930 [FREE Full text] [doi: 10.3390/ijms19071903] [Medline: 29958463]

57. Han J, Zhang L, Zhang J, Jiang Q, Tong D, Wang X, et al. CREBRF promotes the proliferation of human gastric cancer cells via the AKT signaling pathway. Cell Mol Biol (Noisy-le-grand) 2018 Apr 30;64(5):40-45. [doi: 10.14715/cmb/2018.64.5.6] [Medline: 29729692]

58. Xue H, Zhang J, Guo X, Wang J, Li J, Gao X, et al. CREBRF is a potent tumor suppressor of glioblastoma by blocking hypoxia-induced autophagy via the CREB3/ATG5 pathway. Int J Oncol 2016 Aug;49(2):519-528. [doi: 10.3892/ijo.2016.3576] [Medline: 27278737]

59. Tiebe M, Lutz M, de la Garza A, Buechling T, Boutros M, Teleman A. REPTOR and REPTOR-BP regulate organismal metabolism and transcription downstream of TORC1. Dev Cell 2015 May 4;33(3):272-284 [FREE Full text] [doi: 10.1016/j.devcel.2015.03.013] [Medline: 25920570]

60. Lim S, Vos T, Flaxman A, Danaei G, Shibuya K, Adair-Rohani H, et al. A comparative risk assessment of burden of disease and injury attributable to 67 risk factors and risk factor clusters in 21 regions, 1990-2010: a systematic analysis for the global burden of disease study 2010. Lancet 2012 Dec 15;380(9859):2224-2260 [FREE Full text] [doi: 10.1016/S0140-6736(12)61766-8] [Medline: 23245609]

61. Kuo C, Duan Y, Grady J. Unconditional or conditional logistic regression model for age-matched case-control data? Front Public Health 2018;6:57 [FREE Full text] [doi: 10.3389/fpubh.2018.00057] [Medline: 29552553]

\section{Abbreviations}

AUA: Apia urban area

BIA: bioelectrical impedance analysis

BMI: body mass index

CREBRF: Creb 3 Regulatory Factor

DXA: dual-energy x-ray absorptiometry

FBG: fasting blood glucose

GWAS: genome-wide association study

HbA1c: glycated hemoglobin

IRB: institutional review board

NWU: Northwest Upolu

OGTT: oral glucose tolerance test

OLaGA: obesity, lifestyle, and genetic adaptations

ROU: rest of Upolu

WST: Western Samoan tala 
Edited by G Eysenbach; submitted 06.12.19; peer-reviewed by J Ohashi, J Watterson, D Gregori; comments to author 17.01.20; revised version received 24.02.20; accepted 02.03.20; published 23.07.20

Please cite as:

Hawley NL, Pomer A, Rivara AC, Rosenthal SL, Duckham RL, Carlson JC, Naseri T, Reupena MS, Selu M, Lupematisila V, Unasa F, Vesi L, Fatu T, Unasa S, Faasalele-Savusa K, Wetzel AI, Soti-Ulberg C, Prescott AT, Siufaga G, Penaia C, To SB, LaMonica LC, Lameko V, Choy CC, Crouter SE, Redline S, Deka R, Kershaw EE, Urban Z, Minster RL, Weeks DE, McGarvey ST

Exploring the Paradoxical Relationship of a Creb 3 Regulatory Factor Missense Variant With Body Mass Index and Diabetes Among Samoans: Protocol for the Soifua Manuia (Good Health) Observational Cohort Study

JMIR Res Protoc 2020;9(7):e17329

URL: https://www.researchprotocols.org/2020/7/e17329

doi: $10.2196 / 17329$

PMID: $\underline{32706746}$

CNicola L Hawley, Alysa Pomer, Anna C. Rivara, Samantha L Rosenthal, Rachel L Duckham, Jenna C Carlson, Take Naseri, Muagututia Sefuiva Reupena, Melania Selu, Vaimoana Lupematisila, Folla Unasa, Lupesina Vesi, Tracy Fatu, Seipepa Unasa, Kima Faasalele-Savusa, Abigail I Wetzel, Christina Soti-Ulberg, Angela T Prescott, Gloria Siufaga, Corina Penaia, Sophie B. To, Lauren C LaMonica, Viali Lameko, Courtney C Choy, Scott E Crouter, Susan Redline, Ranjan Deka, Erin E Kershaw, Zsolt Urban, Ryan L. Minster, Daniel E. Weeks, Stephen T McGarvey. Originally published in JMIR Research Protocols (http://www.researchprotocols.org), 23.07.2020. This is an open-access article distributed under the terms of the Creative Commons Attribution License (https://creativecommons.org/licenses/by/4.0/), which permits unrestricted use, distribution, and reproduction in any medium, provided the original work, first published in JMIR Research Protocols, is properly cited. The complete bibliographic information, a link to the original publication on http://www.researchprotocols.org, as well as this copyright and license information must be included. 